\title{
Park, People and Biodiversity Conservation in Kaziranga National Park, India
}

Daisy Das ${ }^{\dagger}$

\section{Abstract}

Kaziranga National Park (henceforth, KNP) is a protected area situated in the North Eastern part of India. The park is a World Heritage Site and has a very rich ecosystem. KNP is an attractive tourist destination and occupies a significant place in the life and culture of the people living in this part of the country. Conservation of the park started more than a century ago, and local people have often contested such efforts. This is mainly because indigenous people have been facing displacement and deprivation from resources, which they have been using for centuries. Besides deprivation, wild animals often damage their properties and paddy fields. This leads to resentment among local people and become potential cause of grudge in the form of encroachment, poaching, biodiversity loss, and excessive collection of forest products. As a result, conservation measures may fail to deliver desired outcome. This paper tries to examine the gains and losses for living around KNP and assess the park-people relation. We conduct a case study in some periphery villages of the park and find that people have been suffering from difficulty in rearing livestock and loss caused by wild animal. However, people gain from tourism business. Based on the findings we recommend extension of tourism/allied activities and community welfare measures. The findings may be used to derive policy implication for sustainable management of the park.

Keywords: Kaziranga National Park, Protected Area, Eco Development Committee, Resentment, Tourism, Livelihood, Assam, India

\footnotetext{
${ }^{\dagger}$ Department of Economics, Cotton University (On lien from North Eastern Hill University, Meghalaya), Assam-781001, India,Email:daisy.das@gmail.com

(C) 2017 Das. This is an Open Access article distributed under the terms of the Creative Commons Attribution License (http://creativecommons.org/licenses/by/2.0), which permits unrestricted use, distribution, and reproduction in any medium, provided the original work is properly cited.
} 


\section{Introduction}

Humankind is very much dependent on forests. To protect forests from anthropogenic pressure, forests have been given legal status of Protected Areas (henceforth PA). Such strategy is very much effective in enhancing biodiversity and human well-being (Kalaand Maikhuri, 2014). PA may prove to be as attractive as tourist destinations and thus, provide income and livelihood opportunities (Hussain et al., 2010). People may extract resources like fodder or firewood for sustenance with or without provision in the park management rule from these areas (Thapa \&Chapman, 2010;; Nepal, 2000). In addition, park authority may administer welfare schemes for local people commonly known as 'eco development works'1 (Rishi et al., 2008).

However, neighbouring people often tend to disapprove conservation measures. They may fear eviction or it might be because of restrictions imposed on resource collection from parks and land use (Sims, 2010). Animals often come out of such forests and destroy crops and property of local people (Ogra, 2008). Such immediate loss often overweighs the long term benefits from conservation (Dixon \& Sherman, 1991), especially in poor countries (Arjunan et al., 2006).

The forest of Kaziranga is a PA located in Assam, a state in the North Eastern region of India. The history of wildlife conservation in Kaziranga is more than one hundred years old. Until the end of the $19^{\text {th }}$ century, Kaziranga was a game forest for the elites. To prevent the careless use of the resources, Kaziranga was notified a game reserve in 1905 . Later on, it was declared a reserve forest in 1908 and a game sanctuary in 1916. The status of Kaziranga was again changed to Wildlife Sanctuary in 1950 and upgraded to a National Park in 1974. In 1985, the UNESCO declared

\footnotetext{
1 The eco development programs have been introduced with the aim to improve park-people relation, to prevent poaching with the support of local people, to improve living condition and to provide alternative and sustainable livelihood.
}

Kaziranga a 'World Heritage Site' for its unique natural environment.

In the past, there were settlements with permanent cultivation in the neighbouring areas and people could use the resources of Kaziranga. However, with the acceleration of conservation efforts under successive policy measures taken by the government, the access of people to Kaziranga and its resources has been declining gradually. Successive enactment of other conservation-related laws made people skeptical of the protectionist measures. It stemmed from their concern over restrictions on grazing, fishing, extraction of cane, grass, and firewood, etc. In 1924, there was a strong and collective demonstration and conflicts, which broke out between Assamese landless peasants and Nepali/Assamese grazers (Saikia, 2009). The Forest Department failed to resist the demand of the protesters, and situation remained unchanged until Kaziranga was declared a National Park in 1974.

People have tried to resist different laws implemented for protection of KNP from time to time because of a fear psychosis. There were objections against the six additions to the park during 1985 to 1999, and until present day, these areas have not come under the complete control of park authority. ${ }^{2}$ Thus, local people often contest conservation strategies, and the root of all such conflicts is the fear of losing land and livelihood. Local support may be obtained if PAs can generate incentives in the form of income from rural development based on natural resources. An increase in economic benefits may lead to a change in the attitude of the local communities towards the PA and enhance conservation.

The park authority and local people accuse each other of being insensitive to their respective problems. The remedy to the

${ }^{2}$ First Addition (Burapahar), Second Addition (Sildubi), Third Addition (Panbari RF), Fourth Addition (Kanchanjuri), Fifth Addition (Haldibari) and Sixth Addition (Panpur, RF and stretch of Brahmaputra on the north). 
situation demands a baseline study to assess how park and local people are influencing/affecting each other. To that end, the study identifies and evaluates the costs and benefits of living around KNP. It further examines the resource extraction patterns. Finally, it evaluates the park-people relationship and proposes policy framework to resolve conflicts.

This paper contributes to the literature by highlighting some of the issues specific to wildlife conservation efforts at KNP that have caused conflicts between people living around the park and the authority. A particular PA has a unique location, a particular ecosystem, specific social norms and a unique manenvironment relationship. However, 'same size fits all' policy is not going to help and needs understanding of the particular context of the PA system at different levels along with their advantages and disadvantages. Therefore, it is important to identify and understand the specific problems of KNP before formulation of appropriate policy measures to resolve them. This study is based on primary data and finds that the common people around the park are not much dependent on the park for resources but they always contest conservative measures for the fear of eviction and deprivation. The park authority may think about addressing livelihood strategies for improving park-people relationships for strengthening conservation measures.

Against this backdrop, the current study examines the economics of living around KNP to highlight the interdependence between household economics and wildlife conservation as a way of reducing potential conflicts and increasing the effectiveness of conservation.

The structure of the paper is as follows-it begins with the background issues relating the history of conservation with the present scenario. This is followed by the discussion of the theoretical framework, which underlies the study. After this, we discuss the methodology. Following this, we present the findings under the heading 'Results and Discussion'. Finally, we present two separate sections on recommendation and conclusion respectively.

\section{Theoretical Background}

The main theoretical idea behind this study is to use the sustainable livelihood framework to establish the relation between biodiversity conservation and poverty eradication. This widely accepted framework for promoting sustainable livelihood is developed by Department for International Development (DFID), United Kingdom to promote development practices (DFID, 1999). The livelihood is sustainable if it is capable of recovering people from stress or shock while maintaining capability and perpetuality of assets without undermining its natural resource base (GLOPP, 2008). It is dynamic in the sense that it takes into consideration the institutional structure and links macro perspectives of a policy decision to the micro level. In this framework, livelihood activities aim at poverty reduction without depleting natural resources along with cushioning against vulnerability. The sustainable livelihood framework is motivated by the idea that if local communities enjoy social and economic benefits it may ensure biodiversity conservation.

Different types of livelihood activities were linked to biodiversity conservation in the past depending on the availability of particular resources or amenities. The idea of relating biodiversity conservation with livelihood is not a new concept. Community-based wildlife management started in 1980s with an aim to secure local people's support in protecting wildlife. This strategy argues that if one can harness economic and social gains from wildlife they become enthusiastic to take effort to manage poaching and illicit trade. This strategy may fail because of personal greed or selfishness but such strategies may be very effective if taken in the right circumstances (Booker \& Roe 2017; IIED, 2015). There are also instances of agreement between people and park authority where communities are allowed to extract resources in lieu of their support for conservation. The main idea behind the use of extractive reserve is to harvest the benefits 
from non-timber product like rubber rather than logging. However, use of such resource extraction as a strategy for biodiversity conservation has not been found to be very effective (Agrawal \&Redford, 2006).

Tourism or allied activities may prove to be a useful and effective strategy towards biodiversity conservation. It may be mass tourism or ecotourism. However, the second option has gained tremendous importance in recent times as an effective instrument for biodiversity conservation and enhancing wellbeing of people living near protected forest areas (Mirsanjari et al., 2011; Stankov et al.,2011; Das \& Hussain, 2016). It may generate economic welfare from nature-based activities to compensate people for the loss caused by prohibition on use of natural resource for conservation purpose (Brockington et al., 2012; Sebele, 2010; Kiss, 2004; Al-Sayed \& Al-langawi, 2003;Durbarry, 2004; Gossling, 1999).

Taking into consideration the scenario of KNP, tourism seems to be a better option. Conservation is at stake because rhino poaching is a regular phenomenon in the park (Lopes, 2014). Conservation and expansion of habitat is important for protection of rhinos (Medhi \& Saha, 2014). Therefore, it will be difficult to ensure further conservation if sustainable livelihood opportunities are not developed for the people living in fringe areas.

\section{Methodology}

Kaziranga National Park (KNP), geographically located in the state of Assam in the North Eastern part of India, refers to a vast forest area spreading over two districts, namely, Golaghat and Nagaon. It is a 'World Heritage Site' with two-thirds of the world's one-horned Rhinoceroses, and it hosts a very highly dense tiger population. The park has an area of 430 sq. $\mathrm{km}$ and there is an additional area of 429 sq. $\mathrm{km}$ with a latitude of $26^{\circ} 33^{\prime} \mathrm{N}-26^{\circ} 45^{\prime} \mathrm{N}$ and a longitude $93^{\circ} 9^{\prime} \mathrm{E}-93^{\circ} 36^{\prime} \mathrm{E}$. The additions have been made at different points of time for extending the habitat of wildlife. The main source of data to conduct the study comes from a household survey carried out in the periphery villages of KNP using two stage- sampling in 2012-13. In the first stage, 10 villages have been selected depending on their distance from the core zone of the park. Out of these villages, three villages are situated within the distance of one $\mathrm{km}$ from the core zone, three are located between the distance from $1 \mathrm{~km}$ to $2 \mathrm{~km}$, and four villages are located beyond $2 \mathrm{~km}$ from the core zone. Altogether, from these 10 villages, a total size of 205 households has been surveyed randomly in the study in the second stage. The study does not cover the six additions because these areas legally belong to the park.

The variables used in the survey are both quantitative and categorical in nature. We use descriptive statistics like mean and frequency to derive results from the field survey data and calculate the net cost and benefit. The survey involves few sensitive issues like illegal resource extraction pattern from the park, and they were also asked if they had ever faced any eviction or punitive measures for violating parkrelated laws. To understand the pattern of resource extraction, observations were made about the pattern of livestock herding. They were asked if fish and fuel woods were available inside the park and whether they are allowed by security personnel to collect all these items from inside the park. Respondents were asked about the availability of fish and fuel woods inside the park and if security personnel allowed them to collect anything from inside.

This study includes those benefits and costs, which are can be quantified in monetary terms directly. They are income from tourism and allied activities, benefits from animal vaccination and compensation for wildlife damage. The representative price of vaccine administered is nearly $\$ 1$ (₹65). This is the market value of $\mathrm{HS}+\mathrm{BQ}$ vaccine (vaccine for cattle usually administered in such programs). People in the fringe area of KNP also enjoy benefits from welfare measures implemented by park authority but incidence of such benefit is very rare and estimating these benefits often needs separate in-depth study. Therefore, 
benefits from such items have not been considered in the study.

The valuation of wildlife damage includes the market value of crop loss, repairing costs of houses and market value of other properties destroyed by animals. The present study does not ask about those gains and losses, which occurred in the past as people might have problem in recollection and valuation. Therefore, we ask about such fact and figures related to the previous year. The case of eviction, fine for illegal entry into the park are underreported in the survey. Therefore, cost of protection includes only the cost of animal damage. The study does not involve any rigorous econometric analysis to assess benefits or costs of protection as benefits are often deflated and costs are inflated.

\section{Results and Discussion}

\section{Demographic and Socio-Economic Characteristics of the Respondents}

It has been found from the field survey that the majority of the respondents belong to other backward caste (39 per cent) followed by scheduled tribe (30.2 per cent), general caste (19 per cent) and scheduled caste (11.7 per cent). ${ }^{3}$ The proportion of scheduled caste people is very low because they prefer to live near rivers whereas tribal people prefer to live in the proximity to hills and forests (Das \& Sikdar, 2010). Almost 42.5 per cent of the respondents practice farming of which 15 per

\footnotetext{
${ }^{3}$ Caste is a system of social stratification, which is thousand years old and exclusively found in India. There are several theories based on race and religion, politics, tradition, occupation and evolution in society but it is difficult to identify the exact origin of castes system. It is also believed that caste is deep rooted in the origin of the mechanics of endogamy (Ambedker, 1916). Manusmriti, the authoritarian book on the rules of Hindu religion, stated during $1500 \mathrm{BC}$ that the divine Lord created the Brahamana, the Kshatriya, the Vaishya and the Sudra from his mouth, his arms, his thighs and his feet for smooth functioning of different activities leading to prosperity (Buhler, undated). However, in course of time, the clever and privileged class became powerful and oppressed the lower castes people. The Constitution of India recognises four castes namely, general, scheduled caste, scheduled tribe and other backward caste.
}

cent earn subsidiary income from tourism. Around 21 per cent households earn living by working in tea gardens as labourers and many of them have home gardens. The livelihood of around 20 per cent people depends upon tourism-related business. The remaining households are engaged in jobs in different sectors, including the tourism sector.

\section{Problems Associated with Rearing Livestock}

Scholars argue that people living around PA rear livestock as it contributes to the family income (Hedge \& Enter, 2000) which can offset the loss from damage caused by wildlife. The survey reveals that almost 88.6 per cent of the respondents rear livestock around KNP mainly for three purposes: to use as plough animals, for milk, and to sell (animals/birds like goats, pigs, chickens and pigeons, etc.) as meat in the market. While asked about the problems associated with animal husbandry, 82 per cent revealed that there is non-availability of grassland and 36.6 per cent responded that the locality suffers from scarcity of veterinary doctors. Almost 84.4 per cent of those who were surveyed believed that rearing livestock is no longer a profitable business.

Besides using livestock for meat and milk business, there are other utilities, which rural households may enjoy from these animals. They use cattle for ploughing paddy fields and cow dung as manure and prepare dung cake to use as fuels. Since livestock contributes towards economic welfare, any decline in it will adversely affect the livelihood of rural people.

\section{Wildlife Damage}

The study unravelled that almost 77.6 per cent of the surveyed households have suffered from damage caused by wild animals. It is clear from Table 1 that most of the households suffer from damage caused by wild animals. Crop damage is the most common one. However, at the same time their properties are also at risk. In addition, households reported that there were also instances when human lives were lost due to animal attack (4-5 years ago). The mean value of property damage and crop damage are 
respectively $\$ 55(₹ 3500)$ and $\$ 69$ (₹4437). Loss due to wildlife is the highest ( $\$ 155$ equivalent to ₹9982) for those who suffer from both these two types of loss ( $\left.F_{78}=6.486, p=.001\right)$. Wildlife damage is the highest within $1 \mathrm{~km}$ from the core zone, which is similar to the findings of Mackenzie \& Ahabyona (2012).

Table 1: Distribution of Households Suffering from Wildlife Damage

\begin{tabular}{ll}
\hline Types of Damages & Frequency (in Percent) \\
\hline Destruction of houses & 22 \\
\hline Crop damage & 28.8 \\
\hline Livestock killed & .5 \\
\hline $\begin{array}{l}\text { Loss of property and } \\
\text { crop both }\end{array}$ & 26.3 \\
\hline No such damage & 22.4
\end{tabular}

\section{Source: Author's Calculation from Field Survey}

\section{Effectiveness of Community Welfare Measures}

The KNP authority has a provision of implementing different welfare measures for the people living within its neighbouring boundaries like construction of buildings or school, distribution of water filters, animal vaccinations or eco development works. However, the survey reveals that 76 per cent of the respondents have never availed any such welfare measures. The remaining 24 percent respondents reported that their locality had community hall (1.4percent) and schools (.5 percent) and KNP authority administered animal vaccination (14.6 percent) and health camp (6.8 percent). Our study shows that crop protection measures taken against wild animal raids are not effective. The fences run by electricity and solar energy are often damaged by floods, and it is not maintained properly. A mere 11.7 per cent of the respondents have reported that there is a crop protection committee in their locality. Such committees are mostly formed by local youths without any support from the park authority. There is a provision of compensation for wild animal damage but only 6.8 per cent respondents have received compensation in the last few years. People find the claims process complicated because they have to submit a photograph of animals while destroying. Villagers often fail to do so and refrain from claiming damage. Another important dimension of welfare measures introduced by the park authority is the introduction of the eco-development committee (EDC) to provide opportunities for alternative source of livelihood. However, the survey unfolds that 96 per cent of the respondents are neither aware of the ecodevelopment programs nor are they associated with any EDC.

\section{Resource Extraction from the Park}

Extraction of resource from PA is illegal and respondents may be reluctant to provide information in this regard. However, the field observation has unveiled that most of the livestock had neck belt and were tied with a rope in open space or in the back yard of the household (Figure 1). When we asked our respondents the reason for keeping the livestock in this way-the villagers revealed that they did not set their animals free for the fear of tiger attack. However, the survey found that some villagers collect fish occasionally during floods. During conversation, some of the respondents have reported that the park authority allows villagers to fish during Bihu festival from the water bodies recognised as boundary (Figure 2 ). ${ }^{4}$

The study also revealed that majority of the villagers (except for 3.3 per cent) did not collect fuel wood from the forest for the fear of animal attack (Figure 3). However, they have reported that the forest authority allows them to collect uprooted trees for special causes like marriage ceremony or for cremation. At the same time, it has been found that almost 18 per cent of the respondents collect fuel wood and bamboo during flood from the Karbi Hills, which is adjacent to the park and comprises the buffer zone.

\footnotetext{
${ }^{4}$ Magh Bihu is a festival celebrated in the state of Assam, India in the month of January every year. It is for feasting after harvest.
} 


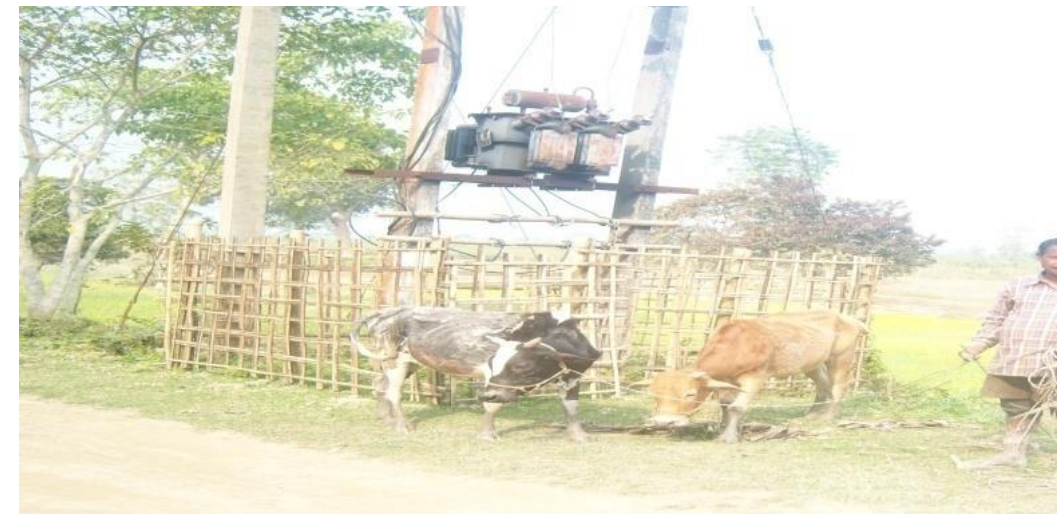

Figure 1: Rearing Livestock with Leads in the Neighbouring Villages of the Park (Source: Author)

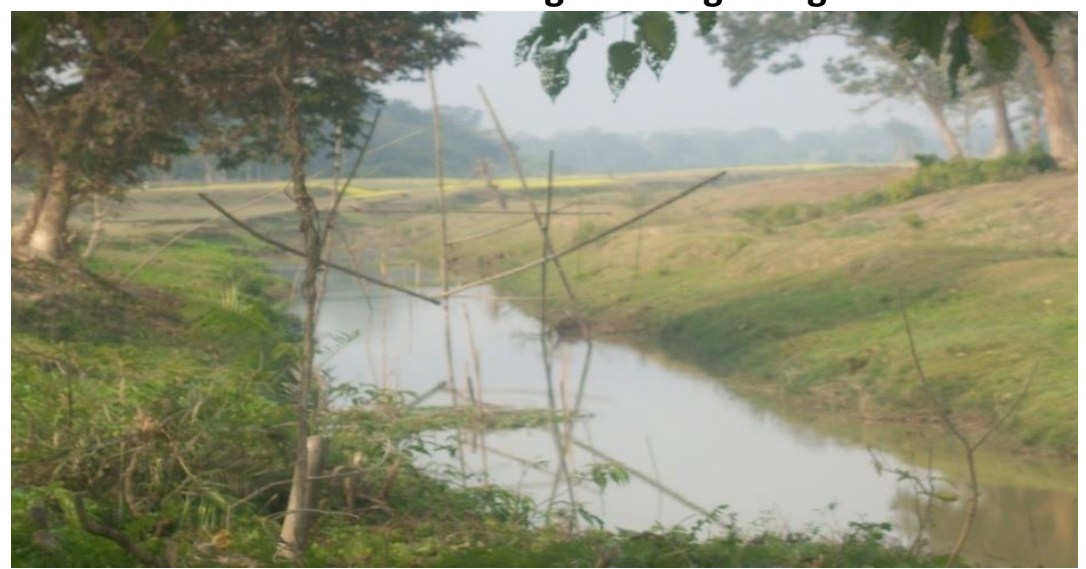

Figure 2: Fish Collection Through Use of Traditional Means During 'Magh Bihu' from Water Body Attached to KNP (Source: Author)

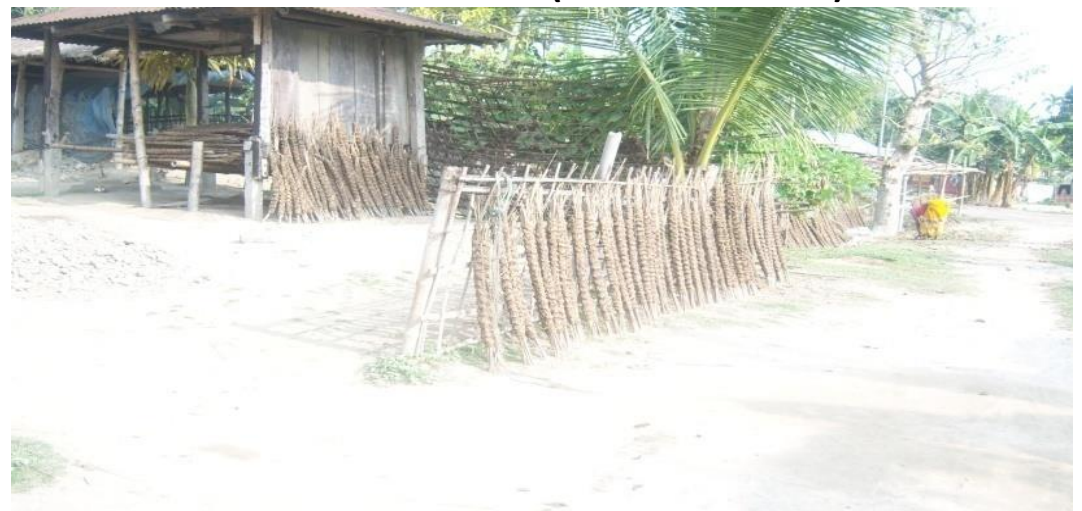

Figure 3: Sticks Layered with Cow Dung and Husks to Use as Fuel for Cooking(Source: Author)

\section{Income from Tourism Activities}

Tourism activities take place in KNP mainly from November to April. Both mass tourism and ecotourism are practiced in KNP (Figures 4 and 5). Domestic and foreign tourists visit the park every year. People get employment by providing services in boarding and lodging, transportation, handicraft as an interpreter and so on (Hussain et al.,2012; Das, 2015). When the park is closed during off-season, tourists' activities often take place around the park. People visiting the park in the off-season spend time in the resorts around the park. These tourists often buy handicrafts and go for jeep safari or joy ride on elephant. Tourists may visit tea garden, orchid garden, enjoy cultural shows or can take taste of ethnic cuisine. Our study reveals that almost 35 per cent people are related to tourism activities. They work as helper, driver, artisan or artists in the cultural shows organised for tourists. Some of them are petty contractor or shop owners.

Tourism activities take place in KNP mainly from November to April. Both mass tourism 
and ecotourism are practised in and around the park. In the off-season, park is kept closed for tourists but off-season tourists' activities often take place around the park. They stay in different lodges, buy handicrafts, go for sightseeing and tourists' spots and visit local restaurants. People may get employment by providing services in boarding and lodging, transportation, as interpreter and handicraft (Hussain et al., 2012). Local people earn income from traditional dance show held in the evening. Our study reveals that almost 35 per cent people are related to tourism activities.

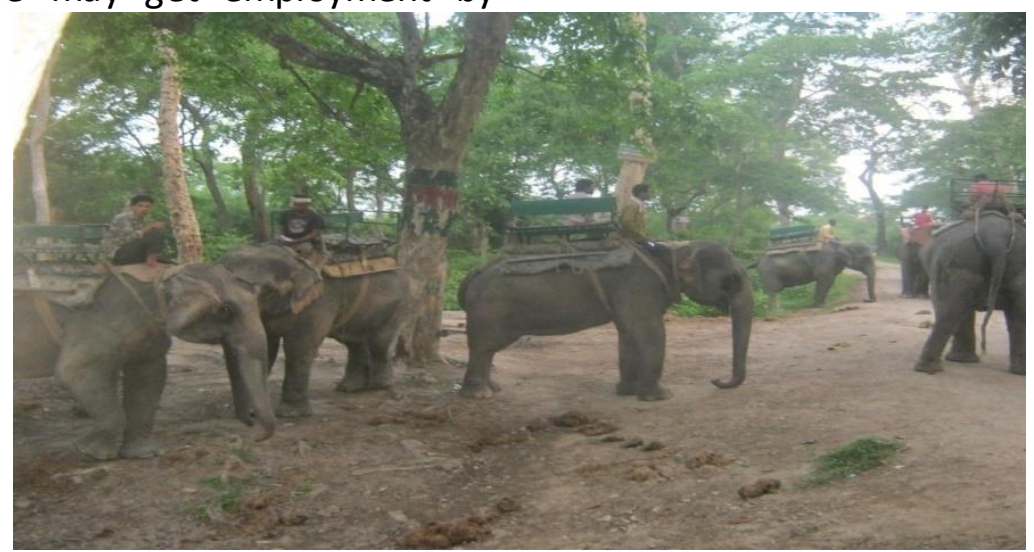

Figure 4: Elephant Safari in the Dawn (Source: Author)

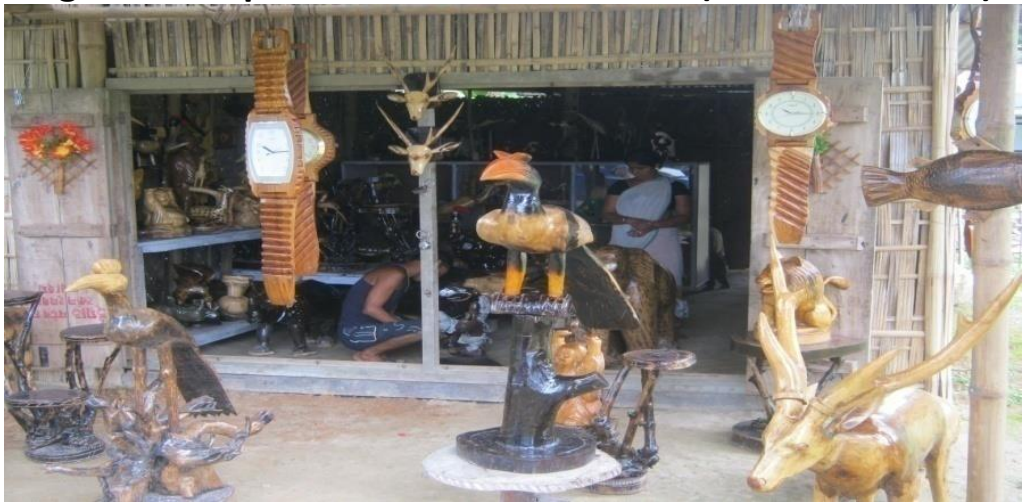

Figure 5: Handicraft Shop (Source: Author)

\section{Problems and Prospects}

After discussing the problems and prospects, a simple exercise has been conducted to find if there is net gain for living around PA. Table 2 shows that the total monetary value of benefit is higher than the monetary value of costs caused by wildlife damage in the previous year. In spite of presence of heavy loss caused by high wildlife damage, the net benefit is high due to growing of tourism.

The findings unfold that per household, the net benefit is \$16(₹995). Amidst the loss from wildlife damage and other problems, it seems to be an overestimation. However, the net gain arises due to surplus income from tourism activities. It has been found by a study that income from tourism in KNP is 40 per cent of the total tourist expenditure (Hussain et al.,
2012). When distance of the study village from the core zone has been taken into account, it has been found from Table1 that the net value of benefit is the highest for those respondents living within the radius of $1 \mathrm{~km}$ and monotonically declines with distance from the central zone. ${ }^{5}$ This is largely due to three reasons: first, tourism activities are concentrated in the core zone and declines gradually; second, total value of wild animal damage is also high near the core zone and declines monotonically; and third, the gain from welfare measures is also nominal in the far-flung areas. The findings confirm inequality in distribution of gain and resemble the findings

\footnotetext{
${ }^{5}$ Central zone is the tourism zone around the Headquarter of KNP located in Kohora.
} 
of Albers et al., (2007). This observation also bears resonance to previous findings (Das, 2015; Das \&Hussain, 2016). It shows that although respondents are living around PA amidst restrictions they still enjoy positive benefits from the existence of the park mainly because of the gain from tourism activities (Mackenzie \& Ahabyona, 2012; Job \& Paesler, 2013).

\section{Park-People Relations in KNP}

Scholars argue that there is often conflict between park authority and people living in and around the parks and people bear negative attitudes towards the parks and authorities (Shyamsundar \&Kramer, 1997; Gillingham \&Lee, 1999). Our findings seemingly unveils that for Kaziranga too there are resentments between the park authorities and the locals
(Mathur et al., 2005; Saikia, 2011; Shrivastava and Heinen, 2007). Hence, to develop a healthy relationship between the people and park authority, it is important to understand and acknowledge residents' perception. When respondents were asked about their opinion regarding their relations with the KNP authority-almost 88 per cent of the respondent revealed negative attitudes towards park authority. They believe that KNP authority nourishes a lackadaisical attitude towards the villagers-any policy measure taken by park authority ignores the potential impact on villagers. It is deep rooted in their minds that the authority considers them as enemies of the park. Table 3 portrays a clear picture about the feelings of villagers towards wildlife and park authority.

\section{Table 2: Benefits and Costs Accrued to Households in Neighbouring Villages (in US dollars and} Rupees)

\begin{tabular}{|c|c|c|c|c|}
\hline & Components & $\begin{array}{l}\text { Less than one } \\
\text { kilometre }\end{array}$ & $\begin{array}{l}\text { Between one } \\
\text { kilometre to two } \\
\text { kilometres }\end{array}$ & $\begin{array}{l}\text { More than two } \\
\text { kilometres }\end{array}$ \\
\hline Costs & $\begin{array}{l}\text { Total monetary } \\
\text { value of damage } \\
\text { due to wild animal } \\
\text { attack }\end{array}$ & $\begin{array}{r}15399 \\
(₹ 962412.00)\end{array}$ & $\begin{array}{r}7806 \\
(₹ 487856.00)\end{array}$ & $\begin{array}{r}7433 \\
(₹ 464556.00)\end{array}$ \\
\hline & $\begin{array}{l}\text { Total income from } \\
\text { tourism }\end{array}$ & $\begin{array}{r}18329 \\
(₹ 1145550.00)\end{array}$ & $\begin{array}{r}10411 \\
(₹ 650670.00)\end{array}$ & $\begin{array}{r}8224 \\
\text { (₹514000.00) }\end{array}$ \\
\hline Benefits & $\begin{array}{l}\text { Total monetary } \\
\text { value of benefits } \\
\text { from vaccination }\end{array}$ & $\begin{array}{r}31 \\
\text { (₹1950.00) } \\
\end{array}$ & $\begin{array}{r}19 \\
(₹ 1170.00) \\
\end{array}$ & $\begin{array}{r}12 \\
\text { (₹780.00) } \\
\end{array}$ \\
\hline & $\begin{array}{l}\text { Total monetary } \\
\text { value of } \\
\text { compensation }\end{array}$ & $\begin{array}{r}136 \\
(₹ 8500.00)\end{array}$ & $\begin{array}{r}120 \\
(₹ 7500.00)\end{array}$ & $\begin{array}{r}16 \\
(₹ 1000.00)\end{array}$ \\
\hline Net benefit & & $\begin{array}{r}3097 \\
(₹ 193588.00)\end{array}$ & $\begin{array}{r}2585 \\
\text { (₹161484.00) }\end{array}$ & $\begin{array}{r}820 \\
\text { (₹51224.00) }\end{array}$ \\
\hline Perhouseh & enefit & 55 (₹3456.00) & 59(₹3670.00) & $8(₹ 488.00)$ \\
\hline
\end{tabular}

Apparently, Table 3 unfolds that people are willing to extend support for conservation effort. However, at the same time they totally oppose the idea of adding new areas to the park, as they feel deprived. At the same time, they believe that the efforts taken by park 
authority are not adequate to improve the relationship. People are not hostile to the wildlife, but the feeling of deprivation always prevents them from supporting the idea of expansion of the park. People are not optimistic about the future of this relation.

Table 3: Opinions in Connection to Park-People Relations (in Per Cent)

\begin{tabular}{lrr} 
Questions & Yes & No \\
\hline Will you support biodiversity conservation in KNP? & 98 & 2 \\
\hline Will you support the idea of expanding the park for conservation? & 0 & 100 \\
\hline Will you feel deprived due to implementation of conservation related measures? & 0 & 100 \\
\hline Will the initiatives taken by park authority for improving park-people relations & 7 & 93 \\
remove bitterness? &
\end{tabular}

\section{Source: Author's Calculation from Field Survey}

\section{Recommendations}

The legal protection of the park has remained a cause of disagreement between the locals and the park authority. Against the global gain, local communities typically receive little incomes but substantial costs related to eviction and exclusion, crop and livestock losses and experience a general deprivation of resource access. These findings are similar to that of previous studies (Vedeld et al., 2012, Adam \&Hutton, 2007, Mackenzie \& Ahabyona, 2012). The study finds that rearing livestock is no longer a profitable business for the people around the park. Majority of the respondents living in the vicinity of the park own livestock but there is scarcity of veterinary doctors and grassland. Park authority has provision for vaccination of cattle in the surrounding villages but the service is very limited. Therefore, there should be provision of more animal care facilities. In this regard, floating veterinary hospital and camps might improve the situation. Besides, the park authority might arrange a day per week when the villagers may be allowed to collect grass from the park, which will help maintain the park (Shrestha \& Alavalapati, 2006). This will also allow regulated use of forest resources (Shah, 2007).

In addition, the welfare measures are meagre. Except for the benefit of vaccination, the people hardly enjoy any tangible benefit from KNP. There exists barely any crop protection measures working effectively at present and crop depredation can reduce farmers' tolerance towards wildlife (Linkie et al., 2007). Although, there is a provision of compensation for wildlife damage, the process is so cumbersome that people seldom apply for any such compensation. Merely 4 per cent of the respondents have been found to be aware of the EDCs. Since the policy behind such welfare aims at obtaining local support for preservation and conservation, it is high time to review the welfare measure before local people become hostile to the park.

The study has found that the gain from living round KNP is concentrated in central zone. Therefore, there should be extensive development of tourism activities in the farflung areas along with expansion of other welfare measures. If the people in the periphery have not been provided with livelihood opportunities, then anti-park activities may develop in these areas. In this direction, ecotourism can help a lot (Nyaupane \& Poudel, 2011). By integrating ecotourism into a broader array of sustainable livelihoods, it is easy to gain support from local people for conservation efforts. This will not only provide sustainable livelihood but also reduce the pressure of tourism from the central to the peripheral areas.

\section{Conclusion}

Based on the findings, it can be said that the park-people relation is not healthy in KNP. It might be because of difficulties in daily life in rearing livestock, wild animal attack or unsatisfactory community welfare measures implemented by park authority. People are benefited from tourism but it is not widespread. To obtain the support of boundary people and to use them as invisible wall, such issues should be addressed well. There should 
be provision of sustainable livelihood from tourism and allied activities to make people understand the existence value of biodiversity for further conservation.

\section{References}

Adam, W.M.,\& Hutton, J. (2007). People, Parks and Poverty: Political Ecology and Biodiversity Conservation. Conservation and Society, 5(2), 147-83.

Agrawal, A.,\& Redford, K. (2006). Poverty, Development and Biodiversity Conservation: Shooting in the Dark, WP 26, Wildlife Conservation Society. Available at http://www.wcs.org (accessed on April 22, 2017).

Ambedker,B.R. (1916). Caste in India, Their Mechanism, Genesis and Development. Patrika Publication, Punjab (India). Available at www.archieve,org/details/castesinlndia 035140mbp (accessed on June13, 2017).

Albers, H. J.,\& Robinson, E.J.Z.(2007). Spatialtemporal Aspects of Cost-benefit Analysis for Park Management: An Example from Khao Yai National Park. Thailand Journal of Forest Economics, 13,129-150.

Al-Sayed, M.,\& Al-langawi, A. (2003). Biological Resources Conservation through Ecotourism Development. Journal of Arid Environment, 54, 225-23.

Arjunan, M., Holmes, C.,Puyravaud, J.P.,\& Davidar, P. (2006). Do Developmental Initiatives Influence Local Attitudes towardConservation? A Case Study from the Kalakad-Mundanthurai Tiger Reserve, India. Journal of Environmental Management, 79, 188-197.

Booker, F.,\& Roe, D. (2017). First Line of Defence? A Review of Evidence on The Effectiveness of Engaging Communities to Tackle Illegal Wildlife Trade. Available atwww.iied.org (accessed on April 22, 2017).

Brockington, D., Igoe, J., \& Soltau, K. S. (2006). Conservation, Human Rights, and
Poverty Reduction. Conservation

Biology, 20, 205-252.

Buhler, G. (undated). Manusmriti: The Laws of Manu, 1500BC. Available atwww.hindubooks.org/manusmriti.pdf (accessed on June 13, 2017)

Das, A.F.,\& Sikdar, M. (2010). Opportunity for Natural Selection among Some Selected Population Groups of Northeast India, Indian J Hum Genet, 16(2), 61-66.

Das, D.,\& Hussain, I. (2016). Does Ecotourism Affect Economic Welfare? Evidence from Kaziranga National Park, India. Journal of Ecotourism, 15, 241-260.

Das, D. (2015). Conflict or Conservation: A Roadmap for Management of Kaziranga National Park, Working Paper, 15-02. Available at www.shsu.edu (accessed on 09 January 2017).

DFID (1999).Sustainable Livelihood Guidance Sheets. Department for International Development. Available at http://www.eldis.org(accessed on April 2017).

Dixon, J. A., \& Sherman,P. B. (1991). Economics of Protected Areas. Ambio 20(2): 68-74.

Durbarry, R. (2004). Tourism and Economic Growth: The Case of Mauritius. Tourism Economics10, 389-401.

Gillingham, S.,\& Lee, P.C. (1999). The Impact of Wildlife-related Benefits on the Conservation Attitude of Local People around the Selous Game Reserve, Tanzania. Environment Conservation, 26(3),218-228.

GLOPP (2008). DFID's Sustainable Livelihoods Approach and its Framework. Available at http://www.glopp.ch (accessed on April 23, 2017).

Gossling, S. (1999). Ecotourism: A Means to Safeguard Biodiversity and Ecosystem Functions. Ecological Economics 29, 303-320.

Hedge, R.,\& Enters. T. (2000). Forest Products and Households Economy: ACase Study 
from Mudumalai Wildlife Sanctuary, Southern India. Environmental Conservation 27(3),250-259.

Hussain, S.A., Barthwal, S.C., Badola, R., Rahman, S. M. T., Rastogi, A., Tuboi, C.,\& Bhardwaj, A.K. (2012). An Analysis of Livelihood Linkages of Tourism in Kaziranga National Park, ANatural World Heritage Site in India. Parks, 18(2),3243.

Hussain, S.S., Giffin, A.W., Moran, D., Robinson, L.A., Fofana, A., \& Paramor,O.A.L. (2010). An Ex Ante Ecological Economic Assessment of the Benefits Arising from Marine Protected Areas Designation in the UK. Ecological Economics, 69(4),828838.

IIED (2015). Conservation, Crime and Communities: Case Studies of Efforts To Engage Local Communities in Tackling Illegal Wildlife Trade. Available at www.iied.org (accessed on April 23, 2017).

Job, H.,\& Paesler, F. (2013). Links between Nature-based Tourism, Protected Areas, Poverty Alleviation and Crises:The Example of Wasini Island (Kenya). Journal of Outdoor Recreation and Tourism, 1-2,18- 28.

Kala, C.P.,\& Maikhuri, R. K. (2011). Mitigating People-park Conflicts on Resource Use through Ecotourism: A Case of the Nanda Devi Biosphere Reserve, Indian Himalaya. Journal of Mountain Science, 8, 87-95.

Kiss, A. (2004). Is Community-based Ecotourism a Good Use of Biodiversity Conservation Funds. Trends in Ecology and Evolution, 19, 232-237.

Linkie, M., Y. Dinata, A. Nofrianto,\& LeaderWilliams, N. (2007). Patterns and Perceptions of Wildlife Crop Raiding In and Around Kerinci Seblat National Park, Sumatra. Animal Conservation, 10,127135.
Lopes, A. A. (2014).Civil Unrest and the Poaching of Rhinos in the Kaziranga National Park, India. Ecological Economics, 103, 20-28.

Mackenzie, C.A.,\& Ahabyona, P. (2012). Elephants in the Garden: Financial and Social Costs of Crop Raiding. Ecological Economics, 75, 72-82.

Mathur, V., Verma, A., Dudley, N., Stolton, S., Hockings, M.,\& James, R.(2007). Kaziranga National Park and World Heritage Site, India: Taking the Long View, in World Heritage Reports 21 World Heritage Forests, UNESCO, Paris. Available athttp://whc.unesco.org (accessed on November 11, 2014).

Medhi, A.,\& Saha, A.K. (2014). Land Cover Change and Rhino Habitat Mapping of Kaziranga National Park, India in M. Singh et al. (eds) Climate Change and Biodiversity: Proceedings of IGU Rohtak Conference-I. Available at https://www.academia.edu (accessed on April 27, 2016).

Mirsanjari, M. M., Molla, M. A., Zarekare, A.,\& Ghorbani, S. (2013). Environmental Impact Assessment of Ecotourism Site's Values. Advances in Environmental Biology, 7, 248-252.

Nepal, S. K. (2000). Tourism in Protected Areas: The Nepalese Himalaya. Annals of Tourism Research 27(3), 661-681.

Nyaupane, G. P.,\& Poudel, S. (2011). Linkages among Biodiversity, Livelihood, and Tourism. Annals of Tourism Research, 38(4),1344-1366.

Ogra, M. V. (2008). Human-wildlife Conflict and Gender in Protected Area Borderlands: A Case Study of Costs, Perceptions, and Vulnerabilities from Uttarakhand (Uttaranchal), India.Geoforum, 39,14081422.

Rishi,P.S., Moghe, S.,\&Upadhay, B. K. (2008). Analysis of Hierarchy of Needs and Motivational Strategies for Ecodevelopment Planning in Two National 
Parks of India Resources. Conservation and Recycling, 52, 707-718.

Saikia, A. (2009). The Kaziranga National Park: Dynamics of Social and Political History, Conservation and Society, 7 (2),113-129.

Saikia, A.(2011). Kaziranga National Park: History, Landscape and Conservation Practices. Economic and Political Weekly, XIVI (32),12-13.

Sebele, L.S. (2010). The Social Impacts of Community-based Tourism: ACase Study of Khama Rhino Sanctuary Trust in the Central District of Botswana (Master's thesis). University of the Witwatersrand, Johannesburg. Available at http://wiredspace.wits.ac.za (accessed on November 15, 2014).

Shah, A. 2007. Management of Protected Areas: Exploring an Alternative in Gir. Economic and Political Weekly, 14, 2923-30.

Shrestha, R. K.,\&Alavalapati, J.R.R. (2006). Linking Conservation and Development: An Analysis of Local People's Attitude towards Koshi Tappu Wildlife Reserve, Nepal. Environment, Development and Sustainability, 8,69-84.

Shrivastava, R. J.,\& Heinen. J.T. (2007). Implications for Conservation and Development Planning: AMicrosite Analysis of Resource Use around Kaziranga National Park. The Journal of Environment Development, 16,207-226.

Shyamsundar, P.,\& Krammer, R. (1997). Biodiversity Conservation: At What Cost? A Study of Households in the Vicinity of Madagaskar's Mantadia National Park.Ambio,26(3),180-184.

Sims, K.R.E. (2010). Conservation and Development: Evidence from Thai Protected Areas.Journal of Environmental Economics and Management, 60, 94-114.

Stankov, U., Stojanovic, V., Dragicevic, V., \& Arsenovic, D. (2011). Ecotourism: An
Alternative to Mass Tourism in Nature Park Stara Planina. Journal of the Geographical Institute, 61, 43-59.

Thapa, S.,\& Chapman, D. S. (2010). Impacts of Resource Extraction on Forest Structure and Diversity in Bardia National Park, Nepal. Forest Ecology and Management, 259 (3),641-649.

Vedeld, P., Angelsen, A.,Bojo, J.,Sjaastad, E.,\&Kobugab, G.K. (2012). Protected Areas, Poverty and Conflicts: A Livelihood Case Study of Mikumi National Park, Tanzania. Forest Policy and Economics, 21, 20-31.

\section{Acknowledgements}

The author is grateful to the University Grant Commission, Government of India, for financial support for the research project entitled "Costs and Benefit of Protection: A Case Study of Kaziranga National Park" in 2012. This paper is an outcome of the project. The author is also thankful to the Department of Economics and International Business, Sam Houston State University, Huntsville, Texas (USA) and Prof. Hiranya K. Nath for providing all facilities and support in accomplishing the paper. Equally, the author is thankful to the editor, editorial board and the anonymous referee for their insightful comments. 